\title{
Innovative Development of Financial Talents in Guangzhou School of Business with the Model of 3A4C Double-level Talent Training
}

\author{
De-Yu CHEN \\ Guangzhou school of business
}

\begin{abstract}
The innovative and applied financial personnel training mode is the core task to improve the quality of talent training in Guangzhou school of business. The key to innovation is the integration of financial talent cultivation factors and market resources. The practice and exploration of financial talents in Guangzhou school of business shows that only by implementing open school-running and international cooperation, can professional setting meet market demand and curriculum setting meet the post demand; and only by improving students' professional quality and forming a unique "value chain", can they innovate the talent training mode and lead the innovative development of financial talents in Guangzhou school of business.
\end{abstract}

Keywords-3A4C; Two-level Financial talents; Innovation and development

\section{INTRODUCTION}

Guangzhou school of business has been continuously exploring the integration of production and education and school-enterprise cooperation with the philosophy of "applied, open and internationalized", and has proposed the "3A4C twolevel financial talent cultivation model" for the first time. "Ability" refers to the three core professional abilities of financial investment students: financial investment practice ability, financial investment management software application ability and professional English application ability. "4C (cooperation)" refers to the cooperative education of four parties of school administration and enterprise. "Dual level" refers to the simultaneous cultivation of investment gold collar (CFA) and financial assistant (ordinary class); In other words, it is divided into two levels to cooperate with the four parties to cultivate applied financial investment talents with three core professional abilities. How to cultivate applied talents:

\section{IMPLEMENT OPEN AND INTERNATIONAL COOPERATION} IN RUNNING SCHOOLS

Talent cultivation cannot be done behind closed doors. We should cultivate innovative and applied talents comprehensively and at multiple levels. Under the framework of "One Belt And One Road", financial personnel training can go abroad and carry out cross-border communication. The financial students should have a global vision, and students can have a master's degree and a doctoral degree, which can provide a space for sustainable development for students' allround development. Open schools must be standardized and specific, and open schools must be forward-looking. In the internationalization of talent cultivation, what we used to export was labor force. Now we need to export capital and rules to cultivate applied undergraduate talents under the framework of "One Belt And One Road"[1].

\section{PROFESSIONAL SETTING MEETS MARKET DEMAND}

We can set the financial direction for the aged according to the market demand to help them manage their money. Professional Settings should be connected to the right gas, such as village and town Banks, inclusive finance is very down-toearth. The development of finance should take technology orientation into account, and we should avoid being sheared by the United States, according to the market demand, find our own profit points, make great efforts around fintech and become a fintech major. We should train students with a wide range of skills and a solid foundation, and consider setting up a major in finance. Currently, financial marketing talents are in short supply, and the direction of financial marketing can also be considered [2]

In terms of talent cultivation, we can expand our thinking and cooperate with other colleges, such as the joint cultivation of big data finance or financial science and technology talents with the computer major, and students can get double degrees of engineering and economics after graduation. The college should innovate in mechanism to form a development pattern of school-enterprise cooperation and mutual benefit and sharing.

\section{COURSE SETTING MEETS POST REQUIREMENTS}

How to set up courses directly affects the quality of talent cultivation? In the course setting, we can implement "one course and many teachers", run double degree classes, and encourage students to apply for the examination. Strengthen resource integration, regulate from the system, but can not be blocked by rules and regulations, such as thesis defense can not be a mere form, thesis defense can choose a few papers, according to excellent, medium, poor three levels of defense, strict requirements, graduates watch, let them know how the real paper is written? How does a real thesis defense work? We should strive to do well in the "guangshang $+"$ article. For example, "guangshang + double degree", "guangshang +CFA", etc., can comprehensively improve the comprehensive quality and ability of students. 
The cultivation of applied talents should attach importance to improving students' professional quality

The talent we cultivate is not the highly selfish elite talent, we want education students know gratitude, integrity and law abiding, can not be mercenary, eager for quick success and instant benefits, students should have a service mentality, service crowd of skills; Do we train students who are oriented toward technology or value? In general, we should focus on the value school, that is, we should emphasize the quality of students, we should cultivate students' attitude of gratitude and responsibility; The teacher should take more students to participate in the competition, improve the enthusiasm of students to participate, students won the prize, learning interest improved naturally, students see the results of learning, learning will be changed from passive learning to active learning, students should be strict requirements, student evaluation of teaching can not be the only standard; The evaluation standard cannot be set too high, should conform to the reality, from the system design for the application of talent escort.

To further shape innovative financial talents, Guangzhou school of businessl should strengthen in the following aspects:

(1) considering the professional group of demand, we will build to a finance, focusing on financial investment and the Internet, in huangpu district around characteristic pillar industries (e.g., modern service industry, financial industry), the association of Internet financial and financial office, guangzhou municipal authorities such as cooperation, micro financial services to local small and medium-sized enterprises, efforts to train high quality applied creative talents. Talent training program is the soul of professional construction. We should timely grasp the market trend, carry out deep cooperation with enterprises, jointly revise talent training program and implant vocational ability training courses.

(2) formulate and implement a new curriculum system and textbook system construction plan on the basis of the survey of professional talent needs and the program of professional training. Strengthen the construction of core courses of Internet finance major, constantly develop new professional courses, use new knowledge carriers to combine the latest progress of financial theory and practice into the teaching of Internet finance major, and realize the new student-centered teaching philosophy. Reform the teaching content of the course, change the active student passive learning into active learning, broaden the students' knowledge and application. The course content should fully reflect the new development and requirements of Banks, securities, financial institutions and state-owned large and medium-sized enterprises.

(3) integrating production and education to improve the quality of personnel training. To "build brand, create the characteristic, enhance core competitiveness" is, in accordance with the "docking, integration, production and education professional course", promoting "three a4c double layers" talent cultivation system, efforts to build a professional teaching combined with more than a class teacher, classroom teaching and the CFA field research, the combination of virtual traders and firm competition, the combination of theory teaching and the combination of "Internet + " layer and module 
of practical teaching system, comprehensive training ", it is believed, racing into, for the new "applied undergraduate financial talent.

The form of graduation design shall be diversified. In addition to the academic paper, the school will continue to implement the forms including survey report, case analysis and exploration of financial practical problems. The college will give guidance to the paper, and will strictly follow the defense procedures, so that the paper will not be out of form.

The basic characteristics of the traditional talent training model are: Since the cultivation target is mainly biased towards the knowledge standard and other reasons, the cultivation environment is mainly carried out on the "ivory tower" campus.

The training factors such as the teaching staff, curriculum content, and teaching environment(including teaching conditions and means) are basically confined to the school classroom. In this way, a basic on-campus cycle model of 5 elements such as training goals-teacherscurriculum content-training environment-students has been formed. Such a factor analysis method can explain the problem and help to guide the practice. The theory of resource dependence holds that the survival and development of the organization body needs to maintain development by obtaining corresponding resources in the surrounding environment, and exchange and interact with the surrounding environment to achieve its own organizational purpose[3]. The Original Control of Order: A Resources Department Peractive, Harper \& amp; Row, New York.] And ... This is especially true for the transformation of local undergraduate universities. Due to the formation of application-oriented talents training models, the transformation of training elements needs to be exchanged with the corresponding superior resources of the surrounding environment in order to break through the limitations of their own factor resources and cultivation modes. Can really adapt to the local economic development. Although the integration of training factors and resources within the school will also have an impact on the training of talents, internal resources are limited, external resources are very broad, and the space and time conditions for innovation are abundant.

It is necessary to break through the limitation of the traditional training mode to establish the training mode of applied talents. The inevitable path to break through the limitations begins with the transformation of the resource state of the cultivation elements. Otherwise, the model of innovative talents can only be done surface work, commonly known as "changing soup without changing medicine", can not produce the desired innovative effect.

At present, the best industries are the financial industry and the science and technology industry. To seize the two major industries, the talents training program of the School of Finance aims to closely meet the needs of the Pearl River Delta market and meet the new needs of banks, securities, investment, private equity and other talents. We must seize the new development of the current financial industry and work hard to develop financial characteristics to serve the local economy. We should not only put schools in place regularly, but also take the lead in teaching management, teaching staff, and the construction of training rooms. We must also set out our own characteristics and position them in micro-finance, such as targeting the needs of the urban market in the Pearl River Delta region and the needs of Jinrongshichang in rural areas. Financial and investment majors can set research or professional directions such as equity investment, quantitative investment, pawn, financial towns, village banks, and inclusive finance.

\section{CONCLUSION}

The sea wide by fish jump, the sky high for birds to fly. Financial institute will be in line with the characteristics of casting brand, quality improve core competitiveness "concept, in the specialty construction, the CFA order class, university-enterprise cooperation, integration production and education, etc., comprehensive, continuous reform and innovation, we will aim at the modern financial industry development needs, and have the courage to bear, good at learning, and train applied innovative talents in an all-round way. Will further take advantage of financial discipline, we combine innovation resources, financial and investment professional efforts to explore the applied talents cultivation and the economic development of the pearl river delta region integration mode, education to build a ZhengJiao QiXie quartet linkage university-enterprise cooperation platform, make the fusion between colleges can realize "docking industry, service industry and breeding industry, leading industry", for the pearl river delta region's economic and social development to provide a steady stream of brainpower [4].

\section{REFERENCE}

[1] Wei yanqi. Research on the relationship between China's financial industrial structure and economic growth [J]. China urban economy, 2012 (3): 25-27.

[2] Mu rongping. Firmly grasp the opportunity of innovation-driven development [N]. Guangming daily, 2017-03-17.

[3] Zhang shixian, li yongping, research summary on the reform of applied talent training model for undergraduates, higher education BBS, October 2010, p5-8.

[4] Pfeffer, j. and Salancik, g. r. (1978), The External Control of Organizations: A Resource Dependence Perspective, Harper \& Row, New York. 